\title{
PERAN UMAT ISLAM DALAM MEWUJUDKAN MASYARAKAT MADANI DI INDONESIA
}

(Konsep dan Strategi Mewujudkan Kesejahteraan Umat yang Demokratis, Adil, dan Makmur)

\author{
Oleh: Ngudi Astuti*
}

\begin{abstract}
The concept of civil society refers to the ideal model of community life in Medina the Prophet Muhammad, which is based on a constitution that called the Charter of Medina. Madani Society is islamization of civil society. Strategies to build madani society in Indonesia can be done with the national integration and political, democratic political system reform, education and political awareness. The role of Muslims in the realization of madani society are as agents of change against the emergence and growth of the intellectuals among the middle class to create the order of social life in a democratic political-economic system is fair.
\end{abstract}

Keywords: Civil society, Muslims, democracy.

\section{Pengertian Masyarakat Madani}

Mayarakat madani dapat diartikan sebagai suatu masyarakat yang beradab dalam membangun, menjalani, dan mamaknai kehidupannya. Masyarakat Madani akan terwujud apabila suatu masyarakat telah menerapkan prinsipprinsip demokrasi dengan baik. Di dalam Al qur'an sudah dijelaskan tentang umat yang terbaik untuk membentuk peradaban manusia yang lebih humanis dan toleran yaitu
"Kamu adalah umat yang terbaik yang dilahirkan untuk manusia, menyuruh kepada yang ma`ruf, dan mencegah dari yang munkar, dan beriman kepada Allah. Sekiranya Ahli Kitab beriman, tentulah itu lebih baik bagi mereka; di antara mereka ada yang beriman, dan kebanyakan mereka adalah orang-orang yang fasik". (QS Ali Imran [3]: 110)

\footnotetext{
* Dosen Fakultas IImu Sosial dan Politik Universitas Jayabaya Jakarta
} 
Konsep "Masyarakat Madani" merupakan penerjemahan atau pengislaman konsep "civil society". (Orang yang pertama kali mengungkapkan istilah ini adalah Anwar Ibrahim dan dikembangkan di Indonesia oleh Nurcholish Madjid.) Pemaknaan civil society sebagai Masyarakat Madani merujuk pada konsep dan bentuk masyarakat Madinah yang dibangun Nabi Muhammad dengan menerapkan Piagam Madinah. Masyarakat Madinah dianggap sebagai legitimasi historis pembentukan civil society dalam masyarakat muslim modern.

\section{Sejarah Masyarakat Madani dalam Peradaban Islam}

Ada dua Masyarakat Madani dalam sejarah yang terdokumentasi sebagai Masyarakat Madani, yaitu:

1) Masyarakat Saba', yaitu masyarakat di masa Nabi Sulaiman.

Allah SWT memberikan gambaran dari Masyarakat Madani dengan firman-Nya dalam Q.S. Saba' ayat 15:

"Sesungguhnya bagi kaum Saba' ada tanda (kekuasaan Tuhan) di tempat kediaman mereka yaitu dua buah kebun di sebelah kanan dan di sebelah kiri. (kepada mereka dikatakan): "Makanlah olehmu dari rezki yang (dianugerahkan)

Tuhanmu dan bersyukurlah kamu kepada-Nya. (Negerimu) adalah negeri yang baik dan (Tuhanmu) adalah Tuhan yang Maha Pengampun”.

2) Masyarakat Madinah setelah terjadi traktat, perjanjjian Madinah antara Rasullullah SAW beserta umat Islam dengan penduduk Madinah yang beragama Yahudi dan beragama Watsani dari kaum Aus dan Khazraj. Perjanjian Madinah berisi kesepakatan ketiga unsur masyarakat untuk saling menolong, menciptakan kedamaian dalam kehidupan sosial, menjadikan Al-Qur'an sebagai konstitusi, menjadikan Rasullullah SAW sebagai pemimpin dengan ketaatan penuh terhadap keputusankeputusannya, dan memberikan kebebasan bagi penduduknya untuk memeluk agama serta beribadah sesuai dengan ajaran agama yang dianutnya.

Secara historis kita lebih mudah secara langsung merujuk kepada "masyarakat"nya Ibnu Khaldun. Deskripsi masyarakatnya justru banyak mengandung muatan-muatan moral-spiritual dan menggunakan agama sebagai landasan analisisnya. Pada kenyataannya masyarakat sipil tidak sama 
dengan Masyarakat Madani. Masyarakat Madani merujuk kepada sebuah masyarakat dan negara yang diatur oleh hukum agama, sedangkan masyarakat sipil merujuk kepada komponen di luar negara. Syed Farid Alatas seorang sosiolog sepakat dengan Syed M. Al Naquib Al Attas (berbeda dengan para sosiolog umumnya), menyatakan bahwa faham Masyarakat Madani tidak sama dengan faham masyarakat Sipil. Istilah Madani, Madinah (kota) dan din (diterjemahkan sebagai agama) semuanya didasarkan dari akar kata din. Kenyataan bahwa nama kota Yathrib berubah menjadi Madinah bermakna di sanalah din berlaku. Secara historispun masyarakat Sipil dan Masyarakat Madani tidak memiliki hubungan sama sekali. Masyarakat Madani bermula dari perjuangan Nabi Muhammad SAW menghadapi kondisi jahiliyyah masyarakat Arab Quraisy di Mekkah. Beliau memperjuangkan kedaulatan, agar ummatnya leluasa menjalankan syari'at agama di bawah suatu perlindungan hukum dan mewujudan cita-cita membentuk madaniyyah (beradab).

\section{Masuknya ke Indonesia}

Masyarakat Madani, konsep ini merupakan penerjemahan istilah dari konsep civil society yang pertama kali dikemukakan oleh Dato Seri Anwar Ibrahim dalam ceramahnya pada simposium Nasional dalam rangka forum ilmiah pada acara Festival Istiqlal, 26 September 1995 di Jakarta (Hamim, 2000:115). Selanjutnya di kembangkan oleh Nurcholis Madjid di Indonesia. Konsep yang diajukan oleh Anwar Ibrahim ini hendak menunjukkan bahwa masyarakat yang ideal adalah kelompok masyarakat yang memiliki peradaban maju. Lebih jelas Anwar Ibrahim menyebutkan bahwa yang dimaksud dengan Masyarakat Madani adalah sistem sosial yang subur yang diazaskan kepada prinsip moral yang menjamin keseimbangan antara kebebasan perorangan dengan kestabilan masyarakat.

Istilah itu diterjemahkan dari bahasa Arab mujtama' madani, yang diperkenalkan oleh Naquib al-Attas, seorang ahli sejarah dan peradaban Islam dari Malaysia, pendiri ISTAC (Ismail, 2000:180-181). Kata "madani" berarti civil atau civilized (beradab). Madani berarti juga peradaban, sebagaimana kata Arab lainnya seperti hadlari, tsaqafi atau tamaddun. Konsep madani bagi orang Arab memang mengacu pada hal-hal yang ideal dalam kehidupan dalam masyarakat. Selanjutnya Alwi Shihab menjelaskan, kaum Muslim awal menjadi "khairu 
ummah" karena mereka menjalankan amar ma'ruf sejalan dengan tuntunan Allah dan rasul-Nya.

Bila merujuk kepada Bahasa Inggris, ia berasal dari kata civil society atau masyarakat sipil, sebuah kontraposisi dari masyarakat militer. Menurut Blakeley dan Suggate (1997), Masyarakat Madani sering digunakan untuk menjelaskan "the sphere of voluntary activity which takes place outside of government and the market."

Perumusan konsep Masyarakat Madani menggunakan projecting back theory, yang berangkat dari sebuah hadits yang mengatakan "Khayr al-Qurun qarni thumma al-ladhi yalunahu thumma al-ladhi yalunahu", yaitu dalam menetapkan ukuran baik atau buruknya perilaku harus dengan merujuk pada kejadian yang terdapat dalam khazanah sejarah masa awal Islam dan bila tidak ditemukan maka dicari pada sumber normatif al-Qur'an dan Hadits (Hamim, 2000: 115-127). Civil society yang lahir di Barat diislamkan menjadi Masyarakat Madani, yaitu suatu masyarakat kota Madinah bentukan Nabi Muhammad SAW. Mereka mengambil contoh dari data historis Islam yang secara kualitatif dapat dibandingkan dengan masyarakat ideal dalam konsep civil society. Masyarakat Madani, dalam kehidupan masyarakat Madinah di bawah
Nabi Muhammad SAW yang masyarakatnya tunduk kepada perjanjian Piagam Madinah (Wikisource bahasa $\begin{array}{llll}\text { Indonesia } & 11 & \text { Des } & 2010\end{array}$ id.wikisource.org/wiki/Piagam_Madinah)

Dialog dialektis antara Islam dan Barat bersifat aktif, karena sebelumnya Barat telah melakukan studi perbandingan dengan peradaban Islam ketika mau merumuskan civil society. Pada waktu itu, Barat sedang dalam cengkeraman pemerintahan otoriter, dan menilai sistem pemerintahan Nabi Muhammad SAW adalah sangat baik. Pengaruh Islam dalam civil society sudah dijelaskan C.G. Weeramantry dan M. Hidayatullah dalam bukunya Islamic Jurisprudence: An International Perspective (1988). Menurutnya, pemikiran John Locke dan Rousseau tentang teori kedaulatan (sovereignty) mendapatkan pengaruh dari pemikiran Islam. Locke ketika menjadi mahasiswa Oxford sangat frustasi dengan disiplinnya, dan lebih tertarik mengikuti ceramah dan kuliah Edward Pococke, profesor studi tentang Arab. Kemudian perhatian pemikiran Locke mengenai problem-problem tentang pemerintahan, kekuasaan, dan kebebasan individu (Azizi, 2000: 94). 
Antara Masyarakat Madani dan Civil society

Secara historis kita lebih mudah secara langsung merujuk kepada "masyarakat"nya Ibnu Khaldun. Deskripsi masyarakatnya justru banyak mengandung muatan-muatan moral-spiritual dan mengunakan agama sebagai landasan analisisnya. Pada kenyataannya masyarakat sipil tidak sama dengan Masyarakat Madani. Masyarakat Madani merujuk kepada sebuah masyarakat dan negara yang diatur oleh hukum agama, sedangkan masyarakat sipil merujuk kepada komponen di luar negara.

Masyarakat Madinah, yang oleh Nurcholish Madjid dijadikan tipologi Masyarakat Madani, merupakan masyarakat yang demokratis. Dalam arti bahwa hubungan antar kelompok masyarakat, sebagaimana yang terdapat dalam poin-poin Piagam Madinah, mencerminkan egalitarianisme (setiap kelompok mempunyai hak dan kedudukan yang sama), penghormatan terhadap kelompok lain, kebijakan diambil dengan melibatkan kelompok masyarakat (seperti penetapan stategi perang), dan pelaku ketidakadilan, dari kelompok mana pun, diganjar dengan hukuman yang berlaku (Nurcholis Madjid 1997).

Kita juga harus meneladani sikap kaum Muslim awal yang tidak mendikotomikan antara kehidupan dunia dan akhirat. Mereka tidak meninggalkan dunia untuk akhiratnya dan tidak meninggalkan akhirat untuk dunianya. Mereka bersikap seimbang (tawassuth) dalam mengejar kebahagiaan dunia dan akhirat. Jika sikap yang melekat pada masyarakat Madinah mampu diteladani umat Islam saat ini, maka kebangkitan Islam hanya menunggu waktu saja. (lihat, Deny Suitor, Membangun Masyarakat Madani, Buletin No.138 , 28 Juli 2006)

Dalam analisis pakar lain, yakni (Muhammad Imarah 1999), setidaknya ada tiga karakteristik dasar dalam Masyarakat Madani. Pertama, diakuinya semangat pluralisme. Artinya, pluralitas telah menjadi sebuah keniscayaan yang tidak dapat dielakkan sehingga mau tidak mau, pluralitas telah menjadi suatu kaidah yang abadi dalam pandangan Alquran. Pluralitas juga pada dasarnya merupakan ketentuan Allah SWT (sunnatullah), sebagaimana tertuang dalam Alquran surat Al-Hujurat (49) ayat 13. Dengan kata lain, pluralitas merupakan sesuatu yang kodrati (given) dalam kehidupan. Dalam ajaran Islam, pluralisme merupakan karunia Allah yang bertujuan mencerdaskan umat melalui perbedaan konstruktif dan dinamis menyesuaikan diri.

Kedua, adalah tingginya sikap toleransi (tasamuh). Baik terhadap saudara 
sesama Muslim maupun terhadap saudara non-Muslim. Landasan normatif dari sikap toleransi dapat kita tilik dalam firman Allah yang termaktub dalam surat AlAn'am ayat 108 .

Ketiga, adalah tegaknya prinsip demokrasi atau dalam dunia Islam lebih dikenal dengan istilah musyawarah. Terlepas dari perdebatan mengenai perbedaan konsep demokrasi dengan musyawarah, saya memandang dalam arti membatasi hanya pada wilayah terminologi saja, tidak lebih. Mengingat di dalam Alquran juga terdapat nilai-nilai demokrasi (surat As-Syura:38, surat

AlMujadalah:11).

\section{Karakteristik Masyarakat Madani}

Ada beberapa karakteristik Masyarakat Madani, diantaranya:

1. Bertuhan, artinya bahwa masyarakat tersebut adalah masyarakat yang beragama, yang mengakui adanya Tuhan dan menempatkan hukum Tuhan sebagai landasan yang mengatur kehidupan sosial.

2. Terintegrasinya individu-individu dan kelompok-kelompok eksklusif ke dalam masyarakat melalui kontrak sosial dan aliansi sosial.

3. Menyebarnya kekuasaan sehingga kepentingan-kepentingan yang mendominasi dalam masyarakat dapat dikurangi oleh kekuatankekuatan alternatif.

4. Dilengkapinya program-program pembangunan yang didominasi oleh negara dengan program-program pembangunan yang berbasis masyarakat.

5. Terjembataninya kepentingankepentingan individu dan negara karena keanggotaan organisasiorganisasi volunter mampu memberikan masukan-masukan terhadap keputusan-keputusan pemerintah.

6. Tumbuhkembangnya kreatifitas yang pada mulanya terhambat oleh rejimrejim totaliter.

7. Meluasnya kesetiaan (loyality) dan kepercayaan (trust) sehingga individu-individu mengakui keterkaitannya dengan orang lain dan tidak mementingkan diri sendiri.

8. Adanya pembebasan masyarakat melalui kegiatan lembaga-lembaga sosial dengan berbagai ragam perspektif.

9. Damai, artinya masing-masing elemen masyarakat, baik secara individu maupun secara kelompok menghormati pihak lain secara adil. 
10. Tolong menolong tanpa mencampuri urusan internal individu lain yang dapat mengurangi kebebasannya.

11. Toleran, artinya tidak mencampuri urusan pribadi pihak lain yang telah diberikan oleh Allah sebagai kebebasan manusia dan tidak merasa terganggu oleh aktivitas pihak lain yang berbeda tersebut.

12. Keseimbangan antara hak dan kewajiban sosial.

13. Berperadaban tinggi, artinya bahwa masyarakat tersebut memiliki kecintaan terhadap ilmu pengetahuan dan memanfaatkan kemajuan ilmu pengetahuan untuk umat manusia.

14. Berakhlak mulia.

Bila kita kaji, masyarakat di negaranegara maju yang sudah dapat dikatakan sebagai Masyarakat Madani, maka ada beberapa prasyarat yang harus dipenuhi untuk menjadi Masyarakat Madani, yakni pertama, adanya democratic governance (pemerintahan demokratis) yang dipilih dan berkuasa secara demokratis. Kedua, adanya democratic civilian (masyarakat sipil) yang sanggup menjunjung nilai-nilai civil security; civil responsibility dan civil resilience.

Apabila diurai, dua kriteria tersebut menjadi tujuh prasyarat Masyarakat Madani sebagai berikut:
1. Terpenuhinya kebutuhan dasar individu, keluarga, dan kelompok dalam masyarakat.

2. Berkembangnya modal manusia (human capital) dan modal sosial (social capital) yang kondusif bagi terbentuknya kemampuan melaksanakan tugas-tugas kehidupan dan terjalinnya kepercayaan dan relasi sosial antar kelompok.

3. Tidak adanya diskriminasi dalam berbagai bidang pembangunan; dengan kata lain terbukanya akses terhadap berbagai pelayanan sosial.

4. Adanya hak, kemampuan dan kesempatan bagi masyarakat dan lembaga-lembaga swadaya untuk terlibat dalam berbagai forum di mana isu-isu kepentingan bersama dan kebijakan publik dapat dikembangkan.

5. Adanya kohesifitas antar kelompok dalam masyarakat serta tumbuhnya sikap saling menghargai perbedaan antar budaya dan kepercayaan.

6. Terselenggaranya sistem pemerintahan yang memungkinkan lembagalembaga ekonomi, hukum, dan sosial berjalan secara produktif dan berkeadilan sosial. 
7. Adanya jaminan, kepastian dan kepercayaan antara jaringanjaringan kemasyarakatan yang memungkinkan terjalinnya hubungan dan komunikasi antar mereka secara teratur, terbuka dan terpercaya.

Tanpa prasyarat tesebut maka Masyarakat Madani hanya akan berhenti pada jargon. Masyarakat Madani akan terjerumus pada masyarakat "sipilisme" yang sempit yang tidak ubahnya dengan faham militerisme yang anti demokrasi dan sering melanggar hak azasi manusia. Dengan kata lain, ada beberapa ramburambu yang perlu diwaspadai dalam proses mewujudkan Masyarakat Madani (lihat DuBois dan Milley 1992).

Ada pendapat lain bahwa karakteristik Masyarakat Madani adalah sebagai berikut:

1. Free public sphere (ruang publik yang bebas), yaitu masyarakat memiliki akses penuh terhadap setiap kegiatan publik, mereka berhak melakukan kegiatan secara merdeka dalam menyampaikan pendapat, berserikat, berkumpul, serta mempublikasikan informasikan kepada publik.

2. Demokratisasi, yaitu proses untuk menerapkan prinsip-prinsip demokrasi . Demokratisasi dapat terwujud melalui penegakkan pilarpilar demokrasi yang meliputi: Lembaga swadaya masyarakat (LSM), pers yang bebas, supremasi hukum, perguruan tinggi, dan partai politik.

3. Toleransi, yaitu kesediaan individu untuk menerima pandanganpandangan politik dan sikap sosial yang berbeda dalam masyarakat, sikap saling menghargai dan menghormati pendapat serta aktivitas yang dilakukan oleh orang/kelompok lain.

4. Pluralisme, yaitu sikap mengakui dan menerima kenyataan mayarakat yang majemuk disertai dengan sikap tulus, bahwa kemajemukan sebagai nilai positif dan merupakan rahmat dari Tuhan Yang Maha Kuasa.

5. Keadilan sosial (social justice), yaitu keseimbangan dan pembagian yang proporsiaonal antara hak dan kewajiban, serta tanggung jawab individu terhadap lingkungannya.

6. Partisipasi sosial, yaitu partisipasi masyarakat yang benar-benar bersih dari rekayasa, intimidasi, ataupun intervensi penguasa/pihak lain, sehingga masyarakat memiliki 
kedewasaan dan kemandirian berpolitik yang bertanggungjawab.

7. Supremasi hukum, yaitu upaya untuk memberikan jaminan terciptanya keadilan. Keadilan harus diposisikan secara netral, artinya setiap orang memiliki kedudukan dan perlakuan hukum yang sama tanpa kecuali.

\section{Kendala Mewujudkan Masyarakat Madani}

Dalam hal ini, Robert Hefner (1998: 1) menyatakan bahwa Masyarakat Madani adalah sebuah impian (dream) suatu komunitas tertentu. Oleh karena itu, Hefner meragukan upaya bangsa Indonesia dalam mewujudkan Masyarakat Madani yang diharapkannya, karena formatnya pun belum jelas. Pendapat Hefner tersebut, memberikan dugaan bahwa Indonesia masih akan jauh dari pembentukan Masyarakat Madani.

Adapun yang masih menjadi kendala dalam mewujudkan Masyarakat Madani di Indonesia diantaranya :

1. Posisi Umat Islam yang berjumlah 85\% tapi kondisinya SDM nya tangat rendah, karena pendidikan yang belum merata.

2. Sistem ekonomi dan kesejahteraan umat. Di dalam ajaran Islam terdapat dua prinsip utama, yakni pertama, tidak seorangpun atau sekelompok orangpun yang berhak mengeksploitasi orang lain; lihat Q.S. As-Syu'ara ayat 183 dan kedua, komitmen Islam yang khas dan mendalam terhadap persaudaraan, keadilan ekonomi dan sosial, maka ketidakadilan dalam pendapatan dan kekayaan bertentangan dengan Islam.(lihat. Q.S Q.S. An-Nahl ayat 71).

3. Management Zakat dan Wakaf yang belum professional (lihat Q.S AlBaqaqarah : 110.)

4. Masih rendahnya pendidikan politik masyarakat.

5. Kondisi ekonomi nasional yang belum stabil pasca krisis moneter.

6. Tingginya angkatan kerja yang belum terserap karena lapangan kerja yang terbatas.

7. Pemutusan Hubungan Kerja (PHK) sepihak dalam jumlah yang besar dan Penanganan TKI yang masih belum maksimal.

8. Kondisi sosial politik yang belum pulih pasca reformasi.

9. Pemerintah yang belum bebas dari KKN.

10. Demokrasi pendidikan belum berjalan dengan lancar. (lihat. 
http;//www.Usman, Husaini Dosen

FIS UN Yogya, "Menuju

Masyarakat Madani melalui

demokrasi Pendidikan" Makalah seminar, 18 Juli 2007.).

\section{Strategi Mewujudkan Masyarakat Madani}

1. Umat Islam harus mempunyai pandangan tentang integrasi nasional dan politik. Pandangan ini menyatakan bahwa sistem demokrasi tidak mungkin berlangsung dalam kenyataan hidup sehari-hari dalam masyarakat yang belum memiliki kesadaran dalam hidup berbangsa dan bernegara.

2. Umat Islam harus mereformasi sistem politik demokrasi, yakni pandangan yang menekankan bahwa untuk membangun demokrasi perlu ditekankan pada usaha demokratisasi yang memberikan impak pada kesejahteraan ekonomi. Revitalisasi bidang politik mesti sejajar dengan perbaikan ekonomi masyarakat.

3. Umat Islam harus mempunyai paradigma membangun Masyarakat Madani yang lebih menekankan proses pendidikan dan penyadaran politik warga negara, khususnya kalangan kelas menengah (middle class) yang terdiri para akademisi, intelektual, budayawan, para pengusaha, dan para mahasiswa sebagai kelompok kritis).

\section{Peran Umat Islam dalam Mewujudkan}

\section{Masyarakar Madani}

Dalam menghadapi perkembangan dan perubahan zaman, maka umat Islam harus berperan aktif dalam mewujudkan Masyarakat Madani.

"Kamu adalah umat yang terbaik yang dilahirkan untuk manusia, menyuruh kepada yang ma'ruf, dan mencegah dari yang munkar, dan beriman kepada Allah. sekiranya ahli Kitab beriman, tentulah itu lebih baik bagi mereka, di antara mereka ada yang beriman, dan kebanyakan mereka adalah orang-orang yang fasik." (Q.S.Ali Imron:110).

Oleh karena itu maka Umat Islam harus menunjukan perannya dalam mewujudkan Masyarakat Madani yaitu antara lain;

1. Melakukan pembenahan kedalam tubuh umat Islam untuk menghapus kemiskinan.

2. Menciptakan keadilan sosial dan demokrasi.

3. Merangsang tumbuhnya para intelektual.

4. Mewujudkan tata sosial politik yang demokratis dan sistem ekonomi yang adil. 
5. Sebagai pengembangan masyarakat melalui upaya peningkatan pendapatan dan pendidikan rakyat.

6. Sebagai advokasi bagi masyarakt yang "teraniaya", tidak berdaya membela hak-hak dan kepentingan mereka (masyarakat yang terkena pengangguran, kelompok buruh, TKI, TKW yang digaji atau di PHK secara sepihak, di siksa bahkan di bunuh oleh majikannya dan lainlain).

7. Sebagai kontrol terhadap negara .

8. Menjadi kelompok kepentingan (interest group) atau kelompok penekan (pressure group) dalam rangka menegakkan kebenaran dan keadilan.

Bangsa Indonesia berusaha untuk mewujudkan Masyarakat Madani yang pada dasarnya adalah masyarakat sipil yang demokratis dan agamis/religius. Dalam kaitannya pembentukan Masyarakat Madani di Indonesia, maka warga negara Indonesia perlu dikembangkan untuk menjadi warga negara yang cerdas, demokratis, dan religius dengan bercirikan imtaq, kritis argumentatif, dan kreatif, berfikir dan berperasaan secara jernih sesuai dengan aturan, menerima semangat Bhineka Tunggal Ika, berorganisasi secara sadar dan bertanggung jawab, memilih calon pemimpin secara jujur-adil, menyikapi mass media secara kritis dan objektif, berani tampil dan kemasyarakatan secara profesionalis, berani dan mampu menjadi saksi, memiliki wawasan yang luas, memiliki semangat toleransi mengerti cita-cita nasional bangsa Indonesia yang demokratis, aman, adil dan makmur bagi seluruh rakyat Indonesia.

\section{Kesimpulan}

Konsep Masyarakat Madani menurut Islam adalah bangunan politik yang: demokratis, partisipatoris, menghormati dan menghargai publik seperti: kebebasan hak asasi, partisipasi, keadilan sosial, menjunjung tinggi etika dan moralitas. Ciri utama Masyarakat Madani Indonesia adalah demokrasi yang menjunjung tinggi nilai-nilai kemanusiaan, masyarakat yang mempunyai faham keagamaan yang berbeda-beda, penuh toleransi, menegakkan hukum dan peraturan yang berlaku secara konsisten dan berbudaya.

Manfaat yang diperoleh dengan terwujudnya Masyarakat Madani ialah terciptanya tatanan masyarakat yang lebih terbuka. Di samping itu, dengan terwujudnya Masyarakat Madani, maka persoalan-persoalan besar bangsa Indonesia seperti: konflik-konflik suku, agama, ras, etnik, golongan, kesenjangan 
sosial, kemiskinan, kebodohan, ketidakadilan pembagian "kue bangsa" antara pusat dan daerah, diharapkan dapat mewujudkan kesejahteraan lahir batin bagi seluruh rakyat, sehingga kekhawatiran akan terjadinya disintegrasi bangsa dapat dicegah.

Strategi membangun Masyarakat Madani di Indonesia dapat dilakukan dengan integrasi nasional dan politik, reformasi sistem politik demokrasi, pendidikan dan penyadaran politik, melalui masyarakat sipil yang mengejewantah dalam berbagai wadah sosial politik di masyarakat, seperti organisasi keagamaan, organisasi profesi, organisasi komunitas, media dan lembaga pendidikan, dan sejenisnya. Dalam konteks ini, maka peran umat Islam amat menentukan dalam artian memberikan kontribusi nyata bagi pembentukan tatanan yang kondusif.

\section{DAFTAR PUSTAKA}

Azizi, A Qodri Abdillah. 2000. Masyarakat Madani Antara Cita dan Fakta: Kajian HistorisNormatif. Dalam Ismail SM dan Abdullah Mukti, Pendidikan Islam, Demokratisasi dan
Masyarakat Madani. Yogyakarta: PustakaPelajar.

Blakeley, Roger dan Diana Suggate (1997), "Public Policy Development", dalam David Robinson, Social Capital and Policy Development, Victoria: Institute of Policy Studies.

Gellner, E. 1995. Membangun Masyarakat Sipil: Prasyarat Menuju Kebebasan (Terjemahan Hasan, I) Bandung: Mizan.

Hamim, Thoha. 2000. Islam dan Civil society (Masyarakat Madani): Tinjauan tentang Prinsip Human Rights, Pluralism dan Religious Tolerance. Dalam Ismail SM dan Abdullah Mukti, Pendidikan Islam, Demokratisasi dan Masyarakat Madani. Yogyakarta: Pustaka Pelajar.

Hartono. 1999. :Perubahan Orientasi Pendidikan Menuju Masyarakat Madani," Cakrawala Pendidikan. Edisi Khusus Mei Th. XVIII No. 2.

http;//www Blogger. Com .Usman, Husaini Dosen FIS UN Yogya, "Menuju Masyarakat Madani melalui demokrasi Pendidikan" Makalah seminar, 18 Juli 2007.

https/www Bloger.com . Masyarakat Madani, Saefur Rochmat, Masyarakat Madani : Dialog Islam dan Modernitas di Indonesia).Dosen Jurusan Sejarah FIS UniV Negeri Yogyakarta. Posted by Taufiq at 1:12 PM0 coment.

Madjid, Nurcholis. 1977. Dinamika Budaya Pesisir dan Pedalaman: 
Menumbuhkan Masyarakat Madani, dalam HMI dan KAHMI Menyongsong Perubahan Menghadapi Pergantian Zaman. Jakarta: Majelis Nasional KAHMI.

Piagam Madinah_ _ Wikisource bahasa Indonesia 11 Des 20101 id.wikisource.org/wiki/Piagam_M adinah -

Schacht, Joseph and C.E. Bosworth (eds.). 1979. The Legacy of Islam. London: Oxford University Press.

Suharto, Edi. 2002. Masyarakat Madani: Aktualisasi Profesionalisme Community Workers Dalam Mewujudkan Masyarakat Yang Berkeadilan. STKS Bandung: Bandung.
Suitor, Deny, Membangun Masyarakat Madani, Center for Moderat muslim Indonesia, Buletin No.138, 28 Juli 2006.

Suwardi, 1999. Demokratisasi Pendidikan dalam Pengajaran Pragmatik Sastra Sebagai Wahana Penciptaan "Masyarakat Madani" Cakrawala Pendidikan, Edisi Khusus Mei. Th. XVIII, No. 2.

Tim Icce UIN Jakarta. 2000. Demokrasi, Hak Asasi Manusia dan Masyarakat Madani. Prenada Media: Jakarta.

Weeramantry, C.G. dan M. Hidayatullah. 1988. Islamic Jurisprudence: An International Perspectives, vondon: The Mcmillan Press. 